\title{
REPRESENTASI MAKNA PERILAKU MUNAFIK DALAM FILM; ANALISIS SEMIOTIKA FILM MUNAFIK 2
}

\begin{tabular}{|c|c|c|c|}
\hline \multicolumn{4}{|c|}{ P-ISSN: 2085-4536 | E-ISSN: 2721-7183 } \\
\hline \multicolumn{4}{|c|}{$\begin{array}{l}\text { Link: } \underline{\text { https://jurnal- }} \\
\text { stidnatsir.ac.id/index.php/dakwah/article/view/44 }\end{array}$} \\
\hline \multicolumn{4}{|c|}{ DOI : https://doi.org/10.38214/jurnaldawahstidnatsir.v2i01.44 } \\
\hline Dikirim: 25-03-2019 & Direvien & $-04-2019$ & Diterbitkan: 17-04-2019 \\
\hline \multicolumn{2}{|c|}{$\begin{array}{c}\text { SAEFUL ROKHMAN } \\
\text { STID Mohammad Natsir - Indonesia } \\
\text { saeful@stidnatsir.ac.id }\end{array}$} & \multicolumn{2}{|c|}{$\begin{array}{c}\text { ELSA } \\
\text { STID Mohammad Natsir - Indonesia } \\
\text { queenelsa834@gmail.com }\end{array}$} \\
\hline
\end{tabular}

\begin{abstract}
ABSTRAK
Tujuan Penelitian: Penelitian ini bertujuan untuk mengungkap representasi makna perilaku munafik dalam film. Metode Penelitian: Kualitatif. Hasil Penelitian: Secara denotasi, perilaku munafik terepresentasikan melalui perilaku dan dialog antara pemain. Melalui tokoh Azman dan Sakinah perilaku munafik secara sifat dan ciri-cirinya mampu ditampilkan. Adanya ingkar janji, khianat dan dusta merupakan salah satu yang termasuk ciri kaum munafik menurut Al-Quran dan Sunnah. Secara konotasi, perilaku munafik yang ada pada film Munafik 2 yaitu menjelaskan bagaimana gambaran sifat-sifat kaum munafik. Dalam satu scene menjelaskan bagaimana Azman yang selama ini berteman baik dengan Adam mengkhianati semua kepercayaan yang telah diberikan kepadanya. Azman terkalahkan oleh hawa nafsu yang ada pada dirinya dengan memfitnah Adam bahwa ia telah berbuat jahat kepada Sakinah. Sementara makna mitos yang terkandung dalam film tersebut ialah Al-Quran dan Sunnah telah menyebutkan sifat dan ciri-ciri orang munafik agar orangorang yang beriman lebih berhati-hati.
\end{abstract}

Kata kunci: representasi, perilaku, munafik, film, semiotika

\section{PENDAHULUAN}


Film mempunyai pengaruh yang sangat besar sekali terhadap jiwa manusia (penonton). Penonton tidak hanya terpengaruh sewaktu atau selama duduk di gedung bioskop, tetapi terus sampai waktu yang cukup lama. Kategori penonton yang mudah terpengaruhi itu biasanya adalah anak-anak dan generasi muda, meski terkadang orang dewasa pun ada. ${ }^{1}$

Sebagai transformasi nilai, film yang hadir dengan tampilan audio visual memberikan kesan tersendiri bagi penontonnya. Ditengah begitu banyaknya film-film yang miskin akan nilai agama dalam masyarakat, muncul beberapa film yang mengandung nilai agama dan memberikan kritik sosial salah satunya yaitu film "Munafik 2".

Representasi menurut Chris Barker adalah konstruksi sosial yang mengharuskan kita mengeksplorasi pembentukan makna tekstual dan menghendaki penyelidikan tentang cara dihasilkannya makna pada beragam konteks. Representasi dalam makna budaya memiliki materialitas tertentu. Mereka melekat pada bunyi, prasasti, objek, citra, buku, majalah, dan program televisi. Mereka diproduksi, ditampilkan, digunakan dan dipahami dalam konteks sosial tertentu. Yasraf Amir Piliang menjelaskan, representasi pada dasarnya adalah sesuatu yang hadir, namun menunjukan sesuatu diluar dirinyalah yang dia coba hadirkan. Representasi tidak menunjukan kepada dirinya sendiri, namun kepada yang lain.

Pengertian representasi nyaris sama dengan pencitraan, yaitu proses pembentukan citra melalui proses yang diterima oleh khalayak, baik secara langsung maupun melalui media sosial atau media massa. Pencirtaan berkaitan dengan empat hal yaitu: pertama, representasi dimana citra merupakan cermin realitas. Kedua, ideology dimana citra menyembunyikan dan memberi gambaran yang salah tentang realitas. Ketiga, citra menyembunyikan bahwa tidak ada realitas. Keempat, citra sama sekali tidak memiliki hubungan dengan realitas apapun. ${ }^{2}$

Dalam pandangan Judy Giles dan Tim Middleon, ${ }^{3}$ represent mempunyai tiga pengertian, yakni to stand in for (melambangkan), to speak or act on behalf of (berbicara atas nama seseorang), dan to re-present edisi Revisi

${ }^{1}$ Elvinari Ardianto, Komunikasi Massa Suatu Pengantar, Bandung: 2007

${ }^{2}$ Ibid, Hal. 97

${ }^{3}$ Dudi Sabil Iskandar dan Rini Lestari, Mitos Jurnalisme, Yogyakarta: CV Andi Offset, 2016, hal. 18 
(menghaadirkan kembali peristiwa yang sudah terjadi). Representasi merupakan sebuah tanda yang tidak sama dengan yang sebenarnya. Hanya saja ia ditautkan melalui realitas yang menjadi referensinya.

Kata representasi menurut Graeme Burton, memiliki definisi yang simple dan menyeluruh. Definisi sederhana menyangkut stereotip, sedangkan versi yang menyeluruh berkaitan dengan sisi media yang tampak dari teknologi. Sedangkan Marcel Danessi memberi definisi representasi sebagai penggunaan tanda (gambar, bunyi dan sebagainya) untuk menghubungkan, menggambar, memotret, dan memproduksi sesuatu yang dilihat, diindra, dibayangkan, atau dirasakan dalam bentuk fisik tertentu. ${ }^{4}$

Kata representasi menunjuk pada penjelasan orang-orang yang membantu mendefinisikan kekhasan kelompok-kelompok dan juga merujuk pada penggambaran berbagai institusi. Representasi juga tidak hanya menunjuk pada permukaan, ia pun menyangkut makna-makna yang dikonstruksi. Singkat kata, representasi menunjuk pada pembuatan makna. Makna tentang dunia dan makna tentang cara memahami dunia. ${ }^{5}$

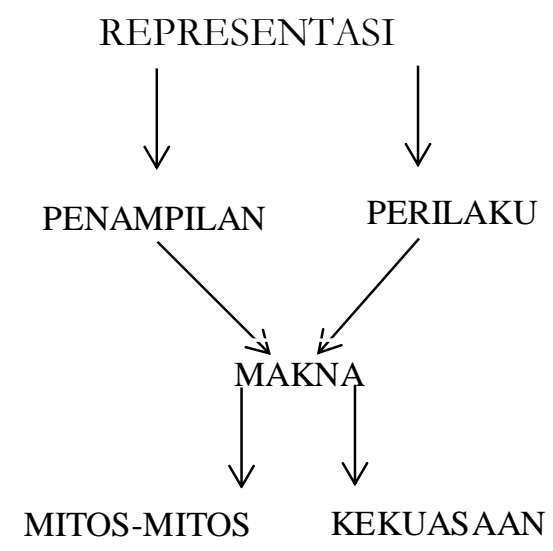

\section{Gambar 1.1 representasi yang dikaitkan dengan makna}

Permukaan representasi terhadap masyarakat melalui kelompokkelmpok terdapat dalam penampilan dan perilaku yang digambarkan. Memahami permukaan ini membawa kita kepada makna-makna tentang

\footnotetext{
${ }^{4}$ Ibid, Hal.19

${ }^{5}$ Ibid, Hal.20-21
} 
representasi. Area-area dominan dalam makna berkaitan dengan mitosmitos kebudayaan dan pandang kelompok itu tentang kekuasann.

Representasi merupakan tindakan untuk menggantikan suatu tindakan yang tidak bisa terjadi atau tidak bisa menghadirkannya sendiri. Ada dua hal yang penting dalam representasi, yaitu representative (yang mempresentasikan orang lain) dan represented (yang dipresentasikan).

Ada dua sistem representasi yang ditemukan Hall, yaitu mental representation dan makna yang terkandung pada bangunan dalam sistem hubungan konseptual dan sistem bahasa serta tanda yang mempresentasikan konsep tersebut. ${ }^{6}$

Dalam temuan Stuart Hall, ada tiga pendekatan dalam teori representasi, yaitu reflektif, intensional, dan konstruksionis. Ia menjelaskan pendekatan reflektif memandang makna dari objek, manusia, ide atau kejadian dalam dunia nyata. Dalam hal itu, bahasa berfungsi sebagai "cermin" untuk merefleksikan yang sebenarnya dalam kehidupan masyarakat. Sedangkan intensional memandang makna berasal dari objek pembuatnya. Pendekatan ketiga konstruksionis, melihat makna dari aspek karakter sosial bahasa. Makna berasal dari pembuat dan menghasilkan makna yang diinginkan. Hal itu mempresentasikan satu konsep dalam masyarakat. Oleh sebab itu, masyarakat akan bisa memberi makna sendiri berlandaskan budaya dan sistem representasi yang digunakan untuk berkomunikasi. ${ }^{7}$

Penelitian ini ingin menjelaskna bagaimana representasi ini bekerja pada film Munafik 2 dengan membedahnya melalui tanda yang tersaji dengan memaknai tanda kedalam makna denotasi, makna konotasi dan mitos yakni bagaimana makna denotasi (gambaran sebuah pertanda) yang bersifat langsung yang dilanjutkan dengan makna konotasi yang bersifat subjektif yang terjadi ketika tanda bertemu dengan perasaan yang kemudian dikaitkan dengan mitos yakni bagimana kebudayaan menjelaskan atau memahami beberapa aspek tentang realitas atau gejala alam.

Munafik adalah sikap dan perbuatan yang berlawanan dengan perkataan dengan maksud untuk mengelabui manusia di sekitarnya. Kemunafikan tak akan pernah mati dari waktu ke waktu. Sifat-sifat kaum

\footnotetext{
${ }^{6}$ Ibid, Hal. 21

${ }^{7}$ Ibid, Hal. 23
} 
munafik akan terus eksis menghiasi orang-orang yang lemah imannya. Karakteristik kaum munafik yang di masa Rasulullah begitu subur menjamur dan begitu banyak dijelaskan dalam Al-Quran dan As-Sunnah. Maka dimasa kekinian karakter-karakter tersebut seakan terus terwarisi dari hari ke hari, dari generasi ke genarasi dan bisa menghiasi jiwa kaum muslimin tanpa disadari. ${ }^{8}$ kaum munafik bukan bagian dari peraih cinta Allah Swt, karena mereka menyimpang dari jalan akidah dan iman. Hati mereka penuh dengan keingkaran terhadap tentara Allah, Al-Quran dan As Sunnah.

Di Awal surat Al-Baqarah, Allah menyebutkan tiga kelompok di dunia ini, mukmin, kafir, dan munafik; empat ayat terkait sifat-sifat orang mukmin, dan dua ayat selanjutnya tentang orang kafir. Sedangkan untuk kaum munafik Allah menyebutkan tiga belas ayat lantaran banyaknya jumlah kaum munafik, luasnya fitnah yang mereka hembuskan, dan besarnya ancaman mereka terhadap Islam dan kaum muslimin.

Cobaan yang diterima umat Islam melalui kaum munafik begitu dahsyat. Pasalnya mereka mengatasnamakan diri sebagai orang Islam yang membela Islam dan loyal kepada Islam, padahal hakikatnya mereka musuhmusuh Islam. Mereka mengeluarkan pancingan permusuhan terhadap Islam pada setiap perbuatan dan ucapan yang oleh orang bodoh dianggap ilmu dan perbuatan baik. Padahal sebenarnya suatu tindakan yang sangat bodoh dan sangat merusak. Betapa banyak benteng Islam telah mereka hancurkan, betapa banyak bangunan pertahanan Islam telah mereka lemahkan pondasinya, lalu mereka robohkan. Berapa banyak syiar Islam telah mereka hapus dan masih banyak lagi pondasi-pondasi Islam yang telah mereka hancurkan.

Agama Islam dan kaum muslimin senantiasa menghadapi cobaan dan bala' yang datang dari kaum munafik. Serangan demi serangan tak henti-hentinya mereka lancarkan pada agama ini. Allah Swt berfirman:

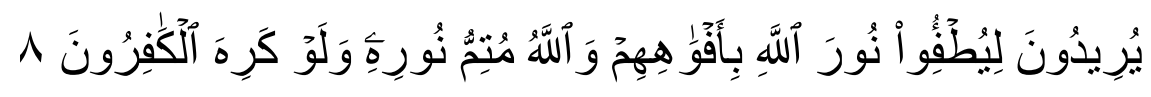

${ }^{8}$ Abdurrahman bin Ali Al Arumi, Menjadi Munafik Tanpa Sadar, Solo : Kiswah Media, 2016, Cet. II 
"Mereka ingin memadamkan cahaya Allah dengan mulut (tipu daya) mereka, tetapi Allah (justru) menyempurnakan cabaya-Nya, walau orang-orang kafir membencinya". (As Shaff: 8)

Imam Ibn Qayyim Al-Jauziyyah ${ }^{9}$ telah berbicara gamblang mengenai kemunafikan dan golongannya dengan gamblang, beliau berkata: "mereka mengenakan pakaian orang-orang beriman, namun bati mereka adalab hati orangorang sesat, rugi, dengki, dan kafir. Modal utama mereka adalah tipuan dan konspirasi. Bekal mereka adalah dusta dan pengkbianatan. Mereka memiliki pemikiran oportunis; agar semua orang bisa senang. Penyakit syubhat dan syabwat telah merusak. mereka dan membinasakannya. Tujuan-tujuan jahat telah mendominasi kehendak mereka dan merusaknya".

Awal mula muncul sifat munafik adalah saat da'wah mulai tersebar ditengah-tengah masyarakat kafir. Agama Islam mulai mendapat tempat di dalam hati umat manusia ke dalam Islam. Pada saat itu kekuasaan orang kafir mulai hilang sedikit demi sedikit, kekuasaan berpindah pada tangan umat Islam. Waktu itulah mulai timbulnya orang-orang munafik, tidak menyatakan iman bersama orang yang beriman dan tidak pula bertahan pada kekafiran dengan secara terus terang, karena takut pada kekuatan ummat Islam. ${ }^{10}$

Karena itu kemunafikan tidak akan terjadi apabila kekuatan dan kekuasaan berada ditangan orang kafir, karena pada waktu itu mereka takut melahirkan kekafirannya secara terus terang dan menentang umat Islam.

Maka dengan adanya asumsi tersebut, penulis mencoba menganalisa lebih jauh mengenai simbol-simbol yang digunakan dalam film Munafik 2 untuk mempresentasikan makna perilaku munafik yang terdapat dalam film tersebut.

Pada penelitian ini peneliti akan lebih fokus membahas tentang representasi perilaku munafik yang terdapat dalam film. Alasan memilih perilaku munafik dalam penelitian ini karena tanda-tanda kemunafikan itu tidak terlihat secara dzobir atau dalam kata lain orang-orang munafik ialah orang-orang yang bermuka dua. Oleh sebab itu peneliti ingin mengetahui

\footnotetext{
${ }^{9}$ Ibid hal 224

${ }^{10}$ Abdul Karim Zaidan, Dasar-dasar Ilmu Da'wah, Jakarta : Media Da'wah, 1980
} 
perilaku ini melalui teori representasi. Representasi dapat diartikan sebagai gambaran mengenai suatu hal yang tedapat dalam kehidupan yang digambarkan melalui suatu media. ${ }^{11}$ pada dasarnya representasi adalah sesuatu yang hadir, namun menunjukan sesuatu diluar dirinyalah yang dia coba hadirkan

Dalam film umumnya dibangun oleh banyak tanda. Tanda-tanda itu termasuk berbagai sistem tanda yang bekerja sama dengan baik dalam upaya mencapai efek yang diharapkan ${ }^{12}$. Untuk mengetahui berbagai kumpulan tanda yang ditampilkan dalam film Munafik 2 salah satunya dengan menggunakan pendekatan analisis semiotika. Dari sekian banyak analisis semiotika, peneliti memilih model analisa Roland Barthes. Dalam semiotika model ini, sistem signifikasi terbagi ke dalam dua tingkatan. Dimana denotasi merupakan tingkatan pertama, sementara konotasi merupakan tingkat kedua. Pada signifikasi tahap kedua yang berhubungan dengan isi, tanda bekerja melalui mitos. Mitos adalah bagimana kebudayaan menjelaskan atau memahami beberapa aspek tentang realitas atau gejala alam. ${ }^{13}$

Film Munafik 2 ini berasal dari Malaysia yang di sutradarai dan di produseri oleh Syamsul Yusof. Film ini menempatkan sebagai film terlaris di Malaysia dan berhasil menduduki peringkat teratas dibelakang lima film lainnya yang tayang pada waktu itu termasuk The Equalizer 2, Crazy Rich Asians, dan Hantu Kak Limah. Film ini berhasil menciptakan sejarah tersendiri di industri film Melayu. Setelah hanya satu bulan tayang film Munafik 2 berhasil menarik lebih dari 3.000 .000 juta penonton. ${ }^{14}$

Film bergenre horor ini menceritakan tentang Adam yang tidak pernah berhenti untuk berbuat kebaikan. Ia masih percaya bahwa ia masih bisa menyelamatkannya imannya, meskipun kematian Maria masih terbawa ke dalam mimpinya, Adam tetap kukuh bahwa dirinya mampu untuk terus berda'wah dan menuntun umat Islam ke jalan yang benar. Bersama

\footnotetext{
${ }^{11}$ Nawiroh Vera, Semiotika dalam Riset Komunikasi, Bogor: Ghalia Indonesia Cet.I, Hal. 96

12 Alex Sobur, Semiotika Komunikasi, Bandung: PT Remaja Rosdakarya, 2013

${ }^{13}$ Alex Sobur, Analisis Teks Media Suatu Pengantar Untuk Analisis Wacana, Analisis Semiotika dan Analisis Framing, Bandung: PT. Remaja Rosdakarya, 2006, Hal. 127-128

${ }^{14}$ https://www.kincir.com/movie/cinema
} 
temannya (Azman) Adam terus derda'wah dan mengajar kebaikan kepada seluruh umat muslim, dan disaat bersamaan Adam terus belajar menjadi ustadz dengan cara yang tepat. Salah satu warga desa bernama Sakinah sedang gelisah karena ayahnya dihinggapi penyakit yang tidak bisa diobati secara medis. Sakinah mencurigai semua ini karena ulah Abu Jal, seorang tokoh yang berusaha menggoyahkan iman masyarakat muslim dengan ajarannya. Abu Jal tidak akan segan-segan untuk membantai setiap laki-laki yang menolak ajarannya, sementara itu jika perempuan ia jadikan sebagai budak pemuas nafsu.

Film Munafik 2 yang didistribusi oleh Skop Production ini terinspirasi dari kisah para nabi dalam memperjuangkan agama Islam. Referensi utama yang digunakan dalam menulis naskah film adalah $\mathrm{Al}$ Quran dan kitab-kitab hadits.

Film Munafik 2 ini merupakan film yang layak untuk disaksikan. Meskipun dibilang horror, namun film ini berbeda dari film horror lainnya. Dialognya dipenuhi dengan ayat-ayat Al-Quran tentang perlindungan dari godaan setan, terbakarnya pengikut dajjal di neraka, banyaknya umat muslim yang tergoda ajaran sesat pada akhir zaman, iman kepada Allah hingga sejarah nabi Musa. Banyak pelajaran yang bisa diambil dari film ini, salah satunya yaitu bagaimana manusia menguatkan akidahnya agar tidak mudah tergoda ajaran sesaat.

Film ini layak dikaji karena peristiwa yang terdapat di dalamnya merupakan cerminan masyarakat pada saat ini yaitu maraknya ajaran-ajaran mengatasnamakan Islam dan mudah goyah dalam mempertahankan keimanannya. Manusia telah berpecah belah dan menempuh jalan yang bermacam-macam. Semua jalan yang ditempuh merupakan jalan yang salah, menyimpang dari kebenaran dan tidak memberikan manfaat apapun.

Maka dari itu, berdasarkan latar belakang diatas, maka penulis ingin mengetahui nilai-nilai aqidah dalam film Munafik 2 dengan mengangkat judul "Representasi Makna Perilaku Munafik Dalam Film (Analisis Semiotika Film Munafik 2)".

Adapun cara yang digunakan peneliti untuk menganalisa data dalam film Munafik adalah menggunakan analisis semiotika. Istilah semiotika muncul pada akhir abad ke-19 oleh filsuf aliran pragmatik Amerika, Charles Sanders Peirce. Yang menjadi dasar semiotika adalah konsep tentang tanda. Tak hanya bahasa dan sistem komunikasi yang tersusun oleh tanda-tanda, 
melainkan dunia itu sendiri seluruhnya terdiri atas tanda-tanda. Bahasa itu sendiri merupakan sistem tanda nonverbal seperti gerak-gerik, bentuk pakaian, serta beraneka praktik sosial konvesional lainnya, dapat dipandang sebagai sejenis Bahasa yang tersusun dari tanda-tanda bermakna yang dikomunikasikan berdasarkan relasi-relasi. ${ }^{15}$

Semiotika adalah suatu ilmu atau metode analisis untuk mengkaji tanda. Tanda-tanda adalah perangkat yang kita pakai dalam upaya berusaha mencari jalan di dunia ini, ditengah-tengah manusia dan bersama-sama manusia. semiotika atau dalam istilah Barthes semiologi, pada dasarnya hendak mempelajari bagaimana kemanusiaan memaknai hal-hal. Memaknai berarti bahwa objek-objek tidak hanya membawa informasi, dalam hal mana objek itu hendak berkomunikasi, tetapi juga mengkonstitusi sistem terstruktur dari tanda.

Sedangkan Preminger berpendapat ${ }^{16}$ bahwa semiotika adalah ilmu tentang tanda-tanda. Ilmu yang menganggap bahwa fenomena sosial/masyarakat dan kebudayaan itu merupakan tanda-tanda. Semiotik mempelajari sistem-sistem, aturan-aturan, konvensi-konvesi yang memungkinkan tanda-tanda tersebut mempunyai arti. Semiotika mengeksplorasi bagaimana makna yang terbangun oleh teks telah diperoleh melalui penataan tanda dengan cara tertentu dan melalui kode-kode budaya.

Suatu tanda menandakan sesuatu selain dirinya sendiri, dan makna ialah hubungan antara suatu objek atau suatu idea dan suatu tanda. Konsep dasar ini mengikat bersama seperangkat teori yang amat luas berurusan dengan simbol, wacana, dan bentuk-bentuk nonverbal, teori-teori yang menjelaskan bagaiamana tanda yang berhubungan dengan maknanya dan bagaimana teori disusun.

Diskursus semiotik ala Barthes merupakan kajian yang cukup menarik apabila digunakan dalam menganalisa sebuah film. Barthes membagi semiotik menjadi dua aspek, yaitu denotasi dan konotasi. ${ }^{17}$

15 Alek Sobur, Semiotika Komunikasi, Bandung: PT Remaja Rosdakarya, 2013, Cet. V, Hal. 13

${ }^{16}$ Nawiroh Vera, Semiotika dalam Riset Komunikasi, Hal.2

${ }^{17}$ Arif Budi Prasetya, Analisis Semiotika Film dan Komunikasi, Malang:

Intrans Publishing, 2019, Hal. 18 
Barthes juga mengkaji aspek yang kedua yaitu konotasi. Dalam istilah yang digunakan Barthes, konotasi dipakai untuk menjelaskan salah satu dari tiga cara kerja dalam tatanan pertandaan kedua. Konotasi menggambarkan interaksi yang berlangsung tatkala tanda bertemu dengan perasaan atau emosi penggunanya dan nilai-nilai kulturalnya. Dapat dikatakan bahwa konotasi merupakan makna yang terbentuk berdasarkan konstruksi pemikiran penggunanya yang didasari dari adanya kebudayaan. Ketika kebudayaan mengonstruksi pemikiran seseorang, maka yang terjadi adalah pemikiran yang berlandaskan dari budaya tersebut. Implikasi yang terjadi adalah dalam memandang setiap fenomena selalu bersumber dari nilai-nilai atau norma budaya yang dijadikan pedoman tersebut. ${ }^{18}$

Masih menurut peminiran Barthes, tanda tidak dapat berdiri sendiri, melainkan bagian dari sebuah sistem. Sistem memiliki berbagai macam makna yang saling berkaitan satu sama lain, dan makna-makna ini ada di dalam tanda. Tanda dapat dipahami lewat berbagai macam cara untuk menemukan maknanya. Tentunya setiap memahami sebuah makna yang terkandung didalam tanda akan terdapat sebuah perbedaan persepsi setiap orang. Semua itu merupakan pengaruh dari budaya yang melatarbelakangi pola pemikirannya. ${ }^{19}$

Roland Barthes juga mencetuskan signifikasi mitos. Bagi orang awam, mitos merupakan sebuah cerita budaya yang belum tentu benar faktanya. Tetapi dalam ranah semiotik Roland Barthes, mitos merupakan cara berpikir dari suatu kebudayaan tentang sesuatu, cara untuk mengonseptualisasikan atau memahami sesuatu. Menurut Barthes, mitos dan ideologi bekerja dengan menaturalkan interpretasi individu yang khas secara historis. Dalam artian, antara mitos dengan suatu ideologi terdapat keterkaitan yakni ada semacam penanaman ideologi pada suatu mitos yang diedarkan di masyarakat. Ideologi tersebut menjadi sebuah pemahaman baru mengenai perspektif terhadap suatu fenomena. Efek yang ditimbulkan adalah adanya suatu konstruksi pola pikir yang memiliki konsep pemahaman tersendiri dalam memaknai fenomena atau secara lebih desktiptif bisa diimplementasikan terhadap suatu karakter atau tokoh yang dianggap penting dan menonjol. ${ }^{20}$

\footnotetext{
${ }^{18}$ Ibid, Hal 18-19

${ }^{19}$ Ibid, Hal 19-20

${ }^{20}$ Ibid, Hal. 21
} 
Salah satu area penting yang dirambah Barthes dalam studinya tentang tanda adalah peran pembaca. Konotasi, walaupun merupakan sifat ahli tanda, membutuhkan keaktifan pembaca agar dapat berfungsi. Barthes secara panjang lebar mengulas apa yang sering disebut sebagai sistem pemaknaan tataran ke-dua, yang dibangun di atas sistem lain yang telah ada sebelumnya. Barthes menciptakan peta tentang bagaimana tanda bekerja: ${ }^{21}$

\begin{tabular}{|c|c|c|}
\hline $\begin{array}{l}\text { 1. signifier } \\
\text { (penanda) }\end{array}$ & $\begin{array}{l}\text { 2. signified } \\
\text { (petanda) }\end{array}$ & \\
\hline \multicolumn{2}{|c|}{$\begin{array}{l}\text { 3. denotatif sign (tanda } \\
\text { denotatif) }\end{array}$} & \\
\hline \multicolumn{2}{|c|}{$\begin{array}{l}\text { 4. Connotative Signifier (penanda } \\
\text { konotatif) }\end{array}$} & $\begin{array}{l}\text { 5. Connotative Signified } \\
\text { (petanda konotatif) }\end{array}$ \\
\hline \multicolumn{3}{|c|}{ 6. Connotative Sign (tanda konotatif) } \\
\hline
\end{tabular}

\section{Table 1.2 Peta Semiotika Roland Barthes}

Tabel di atas menjelaskan tentang perjalanan makna dari sebuah objek yang diamati. Secara mendasar konsep narasi yang diajukan oleh Barthes lebih menekankan terhadap pembentukan sebuah makan. Barthes juga mengawali konsep pemaknaan tanda dengan mengadopsi pemikiran Saussure, namun dia melanjutkannya dengan memasukkan konsep denotasi dan konotasi. Denotative sign (tanda denotasi) lebih merupakan pada penglihatan fisik, apa yang Nampak, bagaimana bentuknya dan seperti apa aromanya. Denotasi merupakan tataran dasar dari pemikiran Bartehs. Level selaanjutnya dalah penanda konotatif dan petanda konotatif. Tataran ini lebih pada bentuk lanjut sebuah pemaknaan. Dalam tataran konotasi, kita sudah tidak melihat dalam tataran fisik semata, namun sudah lebih mengarah pada apa maksud dari tanda tersebut yang tentunya dilandasi oleh peran serta dari pemikiran si pembuat tanda. Hingga pada tataran

\footnotetext{
${ }^{21}$ Nawiroh Vera, Semiotika dalam Riset Komunikasi, Hal. 69
} 
konotasi inilah sebuah tanda dengan maksud tertentu dapat dikomunikasikan. ${ }^{22}$

Jadi, dalam konsep Barthes, tanda konotatif tidak sekedar memiliki makna tambahan, namun juga mengandung kedua bagian tanda denotatif yang melandasi keberadaanya. Sesungghnya, inilah sumbangan Bartehs yang sangat berarti bagi penyempurnaan semiologi Saussure, yang berhenti pada penandaan dalam tataran denotatif. ${ }^{23}$

Dalam kerangka Barthes, konotasi identik dengan oprasi ideologi yang disebutnya sebagai mitos dan berfungsi untuk mengungkapkan dan memberikan pembenaran bagi nilai-nilai dominan yang berlaku dalam suatu periode tertentu. Yang menjadi alasan atau pertimbangan Barthes dengan menempatkan ideology dengan mitos adalah karena baik di dalam mitos maupun ideology, hubungan antara penanda konotatfi dan petanda konotatif terjadi secara termotivasi. ${ }^{24}$

\section{HASIL DAN DISKUSI}

Representasi merupakan tindakan untuk menggantikan suatu tindakan yang tidak bisa terjadi atau tidak bisa menghadirkannya sendiri. Ada dua hal yang penting dalam representasi, yaitu representative (yang mempresentsikan orang lain) dan represented (yang dipresentasikan). Representasi bekerja melalui sistem representasi yang terdiri dari dua komponen penting, yakni melalui konsep pikiran dan bahasa.

Jika dikaitkan antara teori representasi dengan film ini, maka keterkaitannya dengan perilaku munafik sudah tergambarkan dengan baik. Rangkaian adegan yang terdapat dalam film ini sesuai dengan teori representasi. Dalam rangkaian adegan pertama pemeran pembantu utama digambarkan memiliki perilaku munafik yang cukup kuat. Dimana Azman yang selalu membersamai Adam ketika berda'wah kepada masyarakat Dilanjutkan dengan adegan akhir film ini dan didukung dengan dialogdialog yang ada.

Penelitian ini membahas mengenai representasi makna munafik dalam film Munafik 2. Dalam proses analisis ini peneliti menggunakan

\footnotetext{
${ }^{22}$ Arif Budi Prasetya, Analisis Semiotika Film dan Komunikasi, Hal. 12-13

${ }^{23}$ Nawiroh Vera, Semiotika dalam Riset Komunikasi, Hal. 69

${ }^{24}$ Ibid. Hal. 71
} 
analisis semiotika Roland Barthes. Dalam landasan teori telah dijelaskan mengenai munafik. Munafik merupakan menampakkan kebaikan dan menyembunyikan keburukan. Munafik juga memiliki banyak ciri-cirinya.

Representasi perilaku munafik dalam film munafik 2 ini terletak pada scene-scene yang dialami oleh para pemaian dalam kehidupan sehari-hari yang terletak pada perilaku-perilaku dan sifat-sifat yang tersembunyi. Melalui teori representasi Stuart Hall maka perilaku munafik tergambarkan melalui:

Pertama, Pendekatan Reflekif. Pendekatan reflektif yaitu makna yang diproduksi manusia melalui ide, media, objek dan pengalaman-pengalaman di dalam masyarakt secara nyata atau makna diproduksi oleh manusia. Pada pendektan ini sifat munafik yang diketahui adalah manusia berwajah dua. Manusia berwajah dua merupakan salah satu ciri kaum munafik. Film munafik 2 ini berusaha memperlihatkan kepada penonton tentang ciri ini. Hal ini diperlihatkan pada scene pertama, dimana adegan tersebut memperlihatkan Azman yang sedang membersamai ustadz Adam dalam menyampaikan da'wahnya kepada masyarakatnya. Selain adegan pertama yakni adegan yang ke 11 juga memperlihatkan perilaku Azman yang sebenarnya. Sifat munafik telah melekat pada dirinya. Dalam hal ini Imam Bukhori meriwayatkan dalam Al-Adabul Mufrod dari Ammar bin Yasir ia berkata: aku mendengar Rasulullah bersabda: "siapa yang memiliki dua wajab di dunia, ia akan memiliki dua lidah di hari kiamat". ${ }^{25}$

Tanpa kita sadari banyak orang-orang disekitar kita yang mempunyai sifat tersebut. Mereka berbuat baik namun dibelakang kita mereka melakukan hal sebaliknya. Allah sangat mencela sifat bermuka dua dan juga mengancam kaum munafik dengan siksaan api neraka. Allah berfirman:

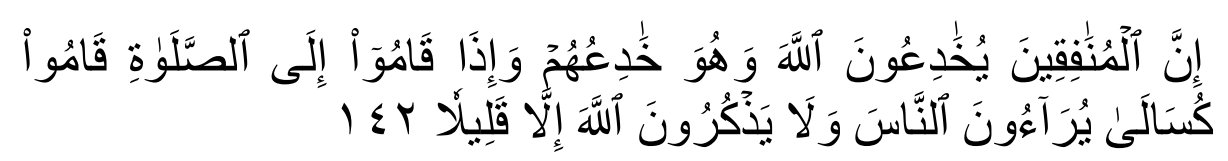

"Sesunggubnya orang-orang munafik itu menipu Allah, dan Allah akan membalas tipuan mereka. Dan apabila mereka berdiri untuk shalat mereka berdiri dengan malas. mereka bermaksud riya (dengan shalat) di hadapan manusia. dan tidaklah mereka menyebut Allab kecuali sedikit sekali". (QS. An-Nisa: 142)

Kedua, Pendekatan Intensioanl. Melalui pendekatan intensional sifat munafik yang tergambarkan adalah sikap dusta, khianat dan ingkar janji

${ }^{25}$ Abdurrahman bin Ali Al-Arumi, Menjadi Munafik Tanpa Sadar, Hal. 82 
sudah tidak asing lagi didengar. Adapaun pendektan intensional yaitu penutur bahasa yang memberikan makna unik pada setiap hasil karyanya atau bahasa sebagai objek.

Dusta, khianat dan ingkar janji adalah tanda-tanda kemunafikan. Banyak ayat yang menjelaskan akan bahaya tiga sifat tersebut salah satunya yaitu firman Allah dalam surat At-taubah:

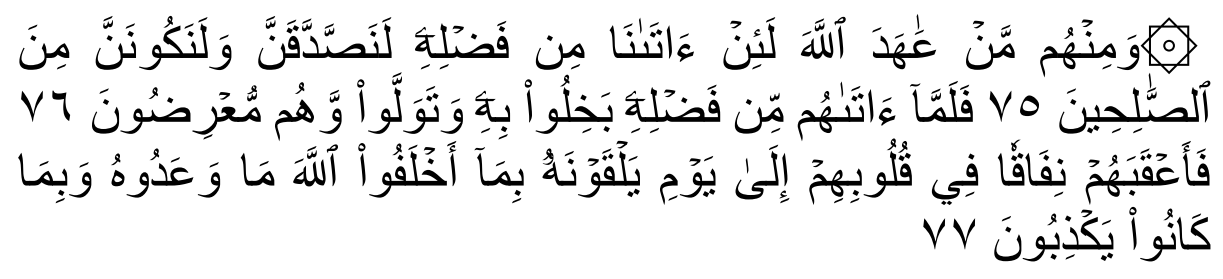

"dan diantara mereka ada orang yang telah berikrar kepada Allah: "Sesunggubnya jika Allah memberikan sebahagian karunia-Nya kepada Kami, pastilah Kami akan bersedekah dan pastilab Kami Termasuk orang-orang yang saleh. Maka setelah Allah memberikan kepada mereka sebahagian dari karunia-Nya, mereka kikir dengan karunia itu, dan berpaling, dan mereka memanglab orang-orang yang selalu membelakangi (kebenaran). Maka Allab menimbulkan kemunafikan pada hati mereka sampai kepada waktu mereka menemui Allah, karena mereka telab memungkiri terhadap Allah apa yang telah mereka ikrarkan kepada-Nya dan juga karena mereka selalu berdusta". (At-Taubah: 75-77)

Film Munafik 2 ingin memberitahukan kepada penonton akan harusnya kehati-hatian dalam menjauhi sifat dusta, khianat dan ingkar janji. Karena sifat tersebut adalag sifat yang tercela dan sangat dibenci Allah. Penonton dengan dapat mudah melihat ketiga sifat tersebut dalam film munafik melalui scene Sakinah yang mengkhianati ustadz Adam yang telah menolongnya.

Ketiga, Pendekatan Konstruksionis. Melalui pendekatan munafik yang diketahui adalah menuruti hawa nafsu. Menuruti hawa nafsu direpresentasikan disaat Azman memfitnah Adam dengan segala perlakuannya. Azman yang saat itu menginginkan posisi dimana Adam berada membuatnya melakukan hal tersebut. Meskipuun pada hakikatnya semua manusia memiliki hawa nafsu terhadap apa-apa yang sesuai dengan kehendaknya. Namun karena kebiasaan orang mengikuti hawa nafsu, syahwat dan emosinya tidak dapat berhenti pada batas yang bermanfaat saja. Karenanya, Allah selalu mencela hawa nafsu dalam kitabnya demikian 
pula dengan Sunnah Rasulullah. Misalnya sabda Rasulullah :"tidak sempuurna iman kalian bingga menjadikan hawa nafsuny selalu tunduk. mengikuti ajaran yang kubawa".

Kaitannya dengan scene yang terdapat dalam film Munafik 2 terlihat pada scene kedepalan, sembilan, sepuluh, dan kesebelas. Pada scene kedelapan dan kesepuluh diceritakan Sakinah dan Azman telah memfitnah Adam atas apa yang telah selama ini Adam lakukan kepadanya. Hawa nafsu yang telah mengalahkan mereka sehinnga mereka tega mengatakan hal tersebt kepada Adam. Pada scene kesembilan juga diceritakan yang menjadi saksi atas perkataan Sakinah. Dengan kemunculannya yang tiba-tiba di depan masyarakat menguatkan bahwa dirinya telah dikalahkan oleh hawa nafsu. Selanjutnya pada scene kesebelas dimana Azman mulai menceritakan hal-hal diluar dugaan, ia iri kepada Adam atas apa yang telah didapatkannya.

Hawa nafsu selalu mengajak manusia kepada keburukan. Masalahmasalah seperti ini harusnya diberikan perhatian khusus kepada masingmasing individu, karena pada intinya semua kesalahan dan dosa yang dilakukan bersumber dari buruknya hati. Allah swt berfirman:

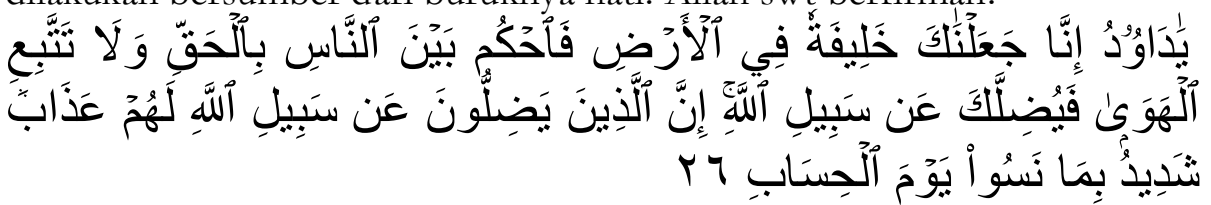

"Dan janganlah kamu mengikuti hawa nafsu, karena ia akan menyesatkan kamu dari jalan Allah. Sesunggubnya orang-orang yang sesat darin jalan Allah akan mendapat azab yang berat, karena mereka melupakan hari perbitungan”. (QS. Shaad: 26)

\section{KESIMPULAN}

Setelah mengamati dan menganalisa bab sebelumnya, penyimpulan hasil pada skripsi ini mengacu kepada permasalahan yang ada. Representasi makna perilaku munafik disampaikan melalui tokoh pembantu utama yang berperan dalam film tersebut, tersaji dalam bentuk dialog, perilaku dan kejadian dalam film Munafik 2. Maka kesimpulan peneliti terhadap masalah tersebut sebagai berikut:

Secara denotasi, perilaku munafik terepresentasikan melalui perilaku dan dialog antara pemain, terutama tokoh Azman dan Sakinah yang ditemukan pada sebelas scene film tersebut. Melalui tokoh Azman dan 
Sakinah perilaku munafik secara sifat dan ciri-cirinya mampu ditampilkan. Adanya ingkar janji, khianat dan dusta merupakan salah satu yang termasuk ciri kaum munafik menurut Al-Quran dan Sunnah.

Secara konotasi, perilaku munafik yang ada pada film Munafik 2 yaitu menjelaskan bagaimana gambaran sifat-sifat kaum munafik. Dimana pada scene-scene yang menunjukan sifat kaum munafik diantaranya, ketika Sakinah lebih memilih dunia dibandingkan akhiratnya. Yaitu saat dimana Sakinah lebih mementingkan anaknya dibandingkan dengan keselamatan ustadz Adam yang teloh menolongnya dari kehajatan yang Abu Jar lakukan padanya. Sedangkan scene lainnya menjelaskan bagaimana Azman yang selama ini berteman baik dengan Adam mengkhianati semua kepercayaan yang telah diberikan kepadanya. Azman terkalahkan oleh hawa nafsu yang ada pada dirinya dengan memfitnah Adam bahwa ia telah berbuat jahat kepada Sakinah.

Sementara makna mitos yang terkandung dalam film tersebut ialah Al-Quran dan Sunnah telah menyebutkan sifat dan ciri-ciri orang munafik agar orang-orang yang beriman lebih berhati-hati. Rasulullah Saw telah memberikan contoh kepada umat Islam bagaimana seharusnya kita bersikap terhadap orang munafik. Beliau menyikapinya dengan menjelaskan kebenaran kepada mereka dan mengharapkan hidayah terhadap mereka, berhenti dari menentang dan menyebarkan fitnah dikalangan umat Islam.

\section{DAFTAR PUSTAKA}

Ahmad Karzon, Anas, Tazkiyatun Nafs, Jakarta: Akbar Media, 2016.

Ali Al Arumi, Abdurrahman, Menjadi Munafik Tanpa Sadar, Solo: Kiswah Media, 2016.

Amirin, Tatang, Menyusun Rencana Penelitian, Jakarta: Raja Grafika Persada, 1995. 
Ardianto, Elvinari, Komunikasi Massa Suatu Pengantar, Bandung: Simbiosa Rekatama Media, 2007.

Ardioanto, Elvinaro, Komunikasi Massa, Bandung: Simbiosa Reakatam Media, 2010.

Budi Prasetya, Arif, Analisis Semiotika Film dan Komunikasi, Malang: Instrans Publising, 2019.

Aziz, Ali, Ilmu Da'wah, Jakarta: Kencana, 2004.

Fahmi, Irham, Perilaku Organisasi Teori, Aplikasi dan Kasus, Bandung: Alfabeta, 2013.

Karim Zaidan, Abdul, Dasar-dasar Ilmu Da'wah, Jakarta: Media Da'wah, 1980.

Mubarok, Achmad, Psikologi Da'wah, Jakarta: Pustaka Firdaus, 2014. Muhammad As Sufyani, Abid, Makar Kaum Munafik, Depok: Pustaka Khazanah Fawaid, 2018.

Musa Alu Nashr, Muhammad, Munafik Menurut Al-Quran dan Sunnah, Jakarta: Daarus Sunnah Press, 2018.

Nashir As Sa'diy, Abdurrahman, Kumpulan Hadits Tazkiyatun Nufus, Jakarta: Griya Ilmu, 2013. 
Nugroho, Sarwo, Teknik Dasar Videografi, Yogyakarta: CV Andi Offset, 2014.

Rakhmat, Jalaludin, Metode Penelitian Kualitatif, Bandung : PT Remaja Rosdakarya, 2014.

Rakhmat, Jalaludin, Psikologi Komunikasi,Bandung: PT Remaja Rosdakarya: 1985.

Sabil Iskandar, Dudi. Dan Rini Lestari, Mitos Jurnalisme, Yogyakarta: CVAndi Offset, 2016.

Sobur, Alex, Semiotika Komunikasi, Bandung: PT Remaja Rosdakarya: 2013.

Analisis Teks Media Suatu PengantarUntuk Analisis Wacana, Analisis Semiotika dan Analisis Framing, Bandung: PT Remaja Rosdakarya: 2006.

Sugiyono, Memahami Penelitian Kualitatif, Bandung: Cv Alfabeta, 2013.

Uchjana Effendy, Onong, Ilmu, Teori dan Filsafat Komunikasi, Bandung: PT Citra Aditya Bakti, 2007.

Umam,Khaerul, Perilaku Organisasi, Bandung: CV Pustaka Setia, 2010. 
Vera, Nawiroh, Semiotika Dalam Riset Komunkasi, Bogor: Ghalia Indonesia, 2014.

Walgito, Bimo, Pengantar Psikologi Umun, Yogyakarta: Penerbit Andi, 2004.

https://www.kincir.com/movie/cinemahttps://www.kincir.com/movie/c inema

https://rumaysho.com/372-saatnya-meninggalkan-musik.html

http://www.shamela.ws

https://ms.m.wikipedia.org/wiki/Skop_Production_Sdn_Bhd

https://id.m.wikipedia.org/wiki/munafik_2 